Ethiopian Journal of Environmental Studies \& Management 9(Suppl. 2): 987 - 996, 2016.

ISSN:1998-0507

Submitted: August 22, 2016

doi: http://dx.doi.org/10.4314/ejesm.v9i2.5S

\title{
ECONOMIC SUSTAINABILITY OF SHEABUTTER PRODUCTION IN KWARA STATE, NIGERIA
}

\author{
*IBRAHIM, H.K., ${ }^{1}$ MUHAMMAD-LAWAL, A., ${ }^{1}$ ADESINA, A.F., ${ }^{1}$ \\ MUHAMMED, A.B. ${ }^{1}$ AND IBRAHIM, A. ${ }^{2}$ \\ ${ }^{1}$ Department of Agricultural Economics and Farm Management, University of Ilorin, \\ P.M.B 1515, Ilorin, Nigeria \\ ${ }^{2}$ National Center for Agricultural Mechanization, P.M.B 1525, Idofian, Ilorin, Kwara State, \\ Nigeria
}

\begin{abstract}
Production of sheabutter has the economic potentials in sustaining income generation for rural dwellers. The potentials of shea nuts productivity could only be achieved when technical efficiency of the processing becomes relevant. The study examines the patterns, efficiency and productivity of processing harvested shea nuts/kernels. This study employs cross-section data that were collected from 160 shea nuts processors in Kwara State and production theory that form the basis of Stochastic Production Frontier (SPF) model were used to analyze the efficiency and productivity of shea nuts processing to sheabutter. The result reveals that the processors from improved technique produced $48 \mathrm{~kg}$ and local processors produced $10 \mathrm{~kg}$ shea butter each from $50 \mathrm{~kg}$ shea nuts in a week. Hence, the technical efficiency of the improved shea nuts processors is higher compared to local processors. The quantity of shea nut and fuel are positively important to the production of sheabutter. However, the education contributes positively to the technical efficiency of the shea nuts processors. Even though, local shea nuts processor increase in output with help of family labour and labour efficiency through household size, but the quantity of shea nut is most important. Therefore, awareness and training exercise should be considered by National Centre for Agricultural Mechanization (NCAM) to extend the improved shea nuts processing technique to the rural sheabutter producers.
\end{abstract}

Key Words: Economic sustainability, Sheabutter production, Stochastic frontier model

\section{Introduction}

Sheabutter is a derivative of shea nuts/kernels which constitute an important source of affordable cooking fat that is widely utilized for domestic purposes such as cooking, skin moisturizer and commercially as an ingredient in a cosmetic, pharmaceutical, and edible product (Abbiw, 1990; Alander, 2004). The sheabutter is naturally rich in Vitamins $\mathrm{A}, \mathrm{E}$, and $\mathrm{F}$ (Okullo et al., 2010). As a cosmetic, it is used as a moisturizer, for dressing hair (Ezema and Ogujiofor, 1992) and for protection against the weather and sun (Bonkoungou, 2001). It was often used as

*Corresponding Author: Ibrahim, H.K.

Email: kobe3trite@yahoo.com 
a substitute for cocoa butter in the chocolate and confectionary industries because it was sweet and oily FAO (1991).

The production of sheabutter has the economical potentials to sustain shea trees (Vitellaria paradoxa) if shea nuts processing is carried out using improved practice for income generation in rural areas. The product is one among NonTimber Forest Products (NTFPs) derives largely from off-reserve forests in many parts of Africa. This is to enhance local livelihood and contribute to environmental sustainability through biodiversity conservation (Shackleton and Shackleton 2004; Ros-Tonen, 2005; Ahenkan and Boon, 2010; Godfred et al., 2015). Aboyella (2002) has noted that shea nuts processing and trading are a major income generating activities that offer employment to rural women and children. In Aboyellas view, sheabutter extraction plays a significant role in poverty alleviation and food security. However, the potential of shea nuts and butter in conserving vulnerable species and reducing the rural poverty. Lovett (2004) concluded that sheabutter is a high-value export to Europe and the United States, where it is considered a luxury.

To derive maximum utility from sheabutter tree, the kernels from its fruits are usually processed into butter for value addition using water, fuel, and labor as critical inputs. It is also noteworthy that the patterns at which the fresh shea nuts/kernels are handled and processed into sheabutter determine the quality of the butter. Research has established that typically unpleasant odor due to the poor quality of sheabutter in West African results from the unreliable step of its post-harvest processing (Lovett, 2004). Although shea nuts have many industrial applications, but its production, processing, and handling into sheabutter are still not reached its full capacity. Meanwhile, the growth of population pressure added to the sheabutter supply gap in meeting demand needs. Even if improved method of producing sheabutter is available, the processing of shea nuts is mostly done using traditional crude processing materials. Hence, this affects the quality and quantity of sheabutter output and reduce the return to processing.

Against this background, the processing patterns of sheabutter by rural households must be assessed as it shall stimulate the household revenue. A sizable of body of literature has embarked on studying shea nuts collection, processing, storage, marketing and its overall value chain (Boffa et al., 1996, Bonkongou, 2001; Aboyella, 2002; Addaquay, 2004; Lovett, 2004; Scherckenberg, 2004; Daniel et al., 2005; Adgidzi, 2008, Yezouma et al., 2009; Ademola et al., 2012; Mohammed et al., 2013; Philip et al., 2014; Abedin et al., 2015; Godfred et al., 2015). However, this study distinguishes its self from the prior mentioned studies by looking at the productivity and technical efficiency of shea nuts processing among rural households in Kwara State, Nigeria. This aspect of the study is important because the research findings shall be added to the literature and provide one of policy paradigms towards fulfilling the Economic Diversification Agenda (EDA) of Nigeria Government and poverty eradication of Sustainable Development Goals (SDG). To meet this objective, this study wants to: 
i. Describe the socio-economic characteristics of shea nuts' processors,

ii. Identify the processing patterns of shea nuta and output level of sheabutter,

iii. Determine the technical efficiency differentials in the processing of shea nut.

iv. Examine the Productivity of the processing patterns of shea nuts,

\section{Research Methodology \\ The Study Area}

In Nigeria, the shea trees thrive efficiently in Niger, Kwara, Kebbi, Kaduna and Oyo State. Kaiama is a Local Government Area in Kwara State, Nigeria. It was founded around 1750AD by a group of immigrants. The founder originated from Niki in the present day Republic of Benin. Its headquarters are in the town of Kaiama. It has an area of $6,971 \mathrm{~km}^{2}$ and a population of 124,164 at the 2006 census (National Population Commission [NPC], 2006).

\section{Sampling Procedure}

A three-stage sampling technique was used. In the first stage, Kaiama was purposively selected because it is a major processing area for shea nuts in Kwara State. In stage two, eight wards were selected at random. These wards include; Kaiama I, Kaiama II, Kaiama III, Kemanji, Wajibe, Gwaria, Gwanbe I, and Gwanbe II. In the final stage, twenty households were selected randomly from each ward making a total of one hundred and sixty (160) respondents sampled for the study. Eighty respondents for the improved and Eighty for local shea nuts processors as the reference group. The study depends on primary data which obtained through the use of a structured questionnaire via personal interview. Analytical Technique

Descriptive statistics such as frequency distribution and percentages was used to group and summarize the data obtained from the field. Also, the Stochastic frontier was used to analyze the output effect and technical efficiency of shea nuts processing.

According to Bravo-Ureta and Riegler (1990), the frontier function models are "neutrally upwardly scaled version of the ordinary least square (OLS) model. Having obtained and compared estimates of technical efficiencies from four different models, they detected that "though levels of technical efficiency vary from one estimation method to the other, yet their results are positively correlated.

Stochastic Frontier Analysis:

$\mathrm{Y}_{\mathrm{i}}=\mathrm{F}\left(\mathrm{X}_{\mathrm{i}}: \beta\right) \exp \left(\mathrm{V}_{\mathrm{i}^{-}} \mathrm{Vi}\right)(\mathrm{i}=1,2,3, . . \mathrm{n})--(\mathrm{i})$ Where, $Y=$ output,

$\mathrm{X}_{\mathrm{i}}=$ the corresponding vector of inputs,

$\beta=$ a vector of the unknown parameter to be estimated;

$\mathrm{F}=$ an appropriate functional form;

$\mathrm{V}=$ asymmetric error component that accounts for random effects and exogenous shock;

$\mathrm{U} \leq \mathrm{O}=$ one side error component that measures technical efficiency.

To develop a model that is flexible and can envelop the data, a Cobb-Douglas production function will be specified and expressed as:

$\operatorname{Ln}(\mathrm{Qty})=\beta_{0}+\beta_{1} \operatorname{Ln}(\mathrm{Ful})+\beta_{2} \operatorname{Ln}(\mathrm{Wtr})+$ $\beta_{3} \operatorname{Ln}(\mathrm{Shn})+\beta_{4} \operatorname{Ln}(\mathrm{Flb})+\mathrm{V}_{1}-\mathrm{V}_{1}---------$ (ii)

Where, Qty = output $(\mathrm{Kg})$;

Ful=fuel (Naira);

Wtr= water (litre)

$\mathrm{Shn}=$ sheanut $(\mathrm{Kg})$ 
$\mathrm{Flb}=$ Family labour proportion $(\%)$;

With $\mathrm{Vi} \sim \mathrm{N}\left(\mathrm{O}, \delta^{2}\right)$

$\mathrm{V}_{1}=\delta_{0}+\delta_{1}(\mathrm{Age})+\delta_{2}(\mathrm{Edu})+\delta_{3}(\mathrm{Hhs})+\delta_{4}$

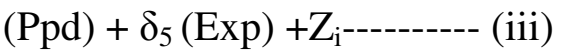

Where, Age $=$ the age of the processor in years;

Edu=level of education;

Hhs = household size;

$\mathrm{Ppd}=$ processing period (hour)

$\mathrm{Exp}=$ processing experience (year)

$\mathrm{Z}_{\mathrm{i}}=$ an error assumed to be randomly and normally distributed.

\section{Results and Discussion}

The socio-economic characteristics may influence shea nuts processing in the area. Table $1,44.4 \%$ and $38.7 \%$ of the sampled respondents were between the age range of 30-40 and 41-50 respectively. Thus, the majority of the sampled respondents were in their middle aged which results in a positive effect in processing. $10.6 \%$ of the respondents are below the age of 30 years. This low involvement of young processors could be due to rural-urban migration of youth for modern education in an urban center.

Table 1: Distribution of the socioeconomic characteristics of respondents $(\mathrm{N}=160)$

\begin{tabular}{lll}
\hline Variables & Frequency & Percent $(\%)$ \\
\hline Age (years) & 17 & \\
$<30$ & 71 & 10.6 \\
$30-40$ & 62 & 44.4 \\
$41-50$ & 10 & 38.7 \\
$>50$ & & 6.3 \\
Marital Status & 7 & \\
Single & 122 & 4.4 \\
Married & 4 & 76.2 \\
Divorced & 17 & 8.8 \\
Widow & 7 & 10.6 \\
Single & & 4.4 \\
Household Size & 25 & \\
1-5 & 70 & 15.6 \\
6-10 & 65 & 43.8 \\
$>10$ & & 40.6 \\
Educational Status & 69 & \\
Formal education & 91 & 43.1 \\
No formal education & & 56.9 \\
Experience (years) & 12 & \\
1-5 & 84 & 7.5 \\
6-10 & 60 & 52.5 \\
11-15 & 4 & 37.5 \\
$>15$ & & 2.5 \\
Basis of Processing & 152 & 95 \\
Full time & 8 & 5 \\
Part time & & \\
\hline
\end{tabular}


The table also shows the marital status of the respondents which reveals that $4.4 \%$ were single, $76.2 \%$ were married, $8.8 \%$ were divorced and $10.6 \%$ were a widow. Married people with large family size have an alternative supply of labour to work during processing especially when the children are available to support in processing activities. This is in agreement with Lovett, (2004); Daniel et al. (2005); Adgidzi, (2008); Ademola et al. (2012); Phillip et al. (2014) who reported that married people have the advantage of employing family labour to assist in the processing activities. Table 1 further revealed that $15.6 \%, 43.8 \%$ and $40.6 \%$ of the respondents were having 1 $5,6-10$ and $>10$ number of people in their household respectively. Hence, family members are capable of providing quality labour during the processing activities. This almost in line with the findings of Bonkongou, (2001); Aboyella, (2002);
Ademola et al. (2012). It was also revealed that $57 \%$ had no formal education and $43.1 \%$ attended school. It can, therefore, be deduced from the table that most processors are educationally disadvantaged. This could have a negative impact on the processor's adoption of innovation on new techniques. In Table $1,7.5 \%$ of the respondents have processing experience of between 1-5 years while $90 \%$ of the respondents have been involved in shea nuts processing for about 6-15 years. This shows that the processors in the study area have a fairly long period of processing experience which will in no doubt be instrumental in the processing level. About $95 \%$ of the respondents are involved in shea nuts processing on fulltime basis while $8 \%$ are involved on parttime basis. This is due to the fact that shea nuts processing activity is their main source of livelihood.

\section{Processing Patterns and Shea nut and shaebutter Output Level}

Table 2: Level of output per week under different processing patterns of shea nuts

\begin{tabular}{lllll}
\hline Output $(\mathrm{kg})$ & Improved & \multicolumn{3}{l}{ Local } \\
\hline & Frequency & $\%$ & Frequency & $\%$ \\
\hline$<10$ & 0 & 0 & 8 & 10 \\
$11-20$ & 1 & 1.2 & 72 & 90 \\
$21-30$ & 6 & 7.5 & 0 & 0 \\
$31-40$ & 24 & 30 & 0 & 0 \\
$41-50$ & 35 & 43.5 & 0 & 0 \\
$>50$ & 14 & 17.5 & 0 & 0 \\
Total & 80 & 100 & 80 & 100 \\
Mean Value & 48.375 & & 10.4625 & \\
Standard Error & 1.03642 & & 0.07323 & \\
Mean Difference & $29.41875^{* * *}$ & & \\
*** indicates the mean difference is statistically significant at $1 \%$ level
\end{tabular}

Table 2 shows that there is a significant difference in the output of improved and local processing techniques with an estimate t-value of 36.4892 at $\mathrm{P}<0.01$. This difference followed a priori expectations. This implied that respondents that used improved technique produced the average of $48 \mathrm{~kg}$ of sheabutter in a week while processors under local processing technique 
produced average of $10 \mathrm{~kg}$ of sheabutter per week each from a bag $(50 \mathrm{~kg})$ of shea nuts. This follows back of the finding in the study by Ademola et al. (2012);
Muhammed et al. (2013) that full adopter process at least 3 bags or more than $21 \mathrm{~kg}$ of shea nuts per week.

Technical Efficiency of Processing Shea nuts to Sheabutter

Table 3: Level of technical efficiency for improved and local processors shea nuts.

\begin{tabular}{lllll}
\hline & Improved & \multicolumn{3}{l}{ Local } \\
\hline Technical Efficiency (TE) & Frequency & $\%$ & Frequency & $\%$ \\
\hline $0.501-0.600$ & 0 & 0 & 12 & 15 \\
$0.601-0.700$ & 0 & 0 & 32 & 40 \\
$0.701-0.800$ & 6 & 7.5 & 26 & 32.5 \\
$0.801-0.900$ & 14 & 17.5 & 10 & 12.5 \\
$0.901-1.00$ & 60 & 75 & 0 & 0 \\
Total & 80 & 100 & 80 & 100 \\
Min TE & 0.743 & & 0.593 & \\
Max TE & 0.996 & & 0.835 & \\
Mean TE & 0.930 & & 0.780 & \\
\hline
\end{tabular}

In Table 3, the technical efficiency of the improved processors ranged from $74.3-99.6 \%$ with a mean of $93 \%$. This mean indicates that given the level of technology of the improved shea nuts processors, only $7 \%$ is left to increase their technical production capacity. This is confirmed by the result of the gamma value in table 4 where only 0.13 of the variation in the output of the processor was attributed to their inefficiency. The technical efficiency of the unimproved processors ranged from $5.3-83.5 \%$ with an average of $78 \%$. This implies that there is a need to raise the level of output. This finding is consistent with the outcome of a study on the effect of adoption of improved sheabutter processing technology on women's livelihood and microenterprise growth by Muhammed et al. (2013). The study concluded that adoption of improved technology has positive effect on the livelihoods of women and enterprise growth (Boffa et al., 1996, Bonkongou, 2001; Aboyella, 2002; Addaquay, 2004; Lovett, 2004; Scherckenberg, 2004; Daniel et al., 2005; Adgidzi, 2008, Yezouma et al., 2009; Muhammed et al., 2013). This is to allow the households to cater for their children's education, ability to meet the health needs of their family, improvement in access to household food and improvement in access to households' assets (Muhammed et al., 2013). 
Stochastic Result of Sheabutter Production

Table 4: Stochastic estimates of the sheabutter production from shea nuts

\begin{tabular}{cccc|ccc}
\hline & \multicolumn{3}{c|}{ Improved } & \multicolumn{3}{c}{ Local } \\
\hline Variables & Coeff. & Std. error & t.value & Coeff. & Std. error & t.value \\
\hline Costant & 0.97 & 1.05 & 0.92 & -1.1 & 0.97 & -1.13 \\
Age & 0.02 & 0.12 & 0.20 & 0.006 & 0.02 & 0.38 \\
Edu & $0.05^{* * *}$ & 0.01 & 4.60 & 0.08 & 0.12 & 0.65 \\
Pdp & -0.57 & 0.92 & -0.62 & $0.16^{* *}$ & 0.06 & 2.54 \\
Hhs & $-0.01^{* *}$ & 0.61 & -2.2 & 0.17 & 0.15 & 1.16 \\
Exp & 0.46 & 0.35 & 1.3 & 0.02 & 0.06 & 0.41 \\
Constant & 12.9 & 1.17 & 11.05 & 8.23 & 0.34 & 24.3 \\
Ful & $3.94^{* * *}$ & 1.03 & 3.84 & 0.11 & 0.08 & 1.35 \\
Wtr & 1.55 & 1.08 & 1.44 & 0.07 & 0.1 & 0.7 \\
Shn & $0.014^{* * *}$ & 0.002 & 6.02 & $0.004^{* * *}$ & 0.0007 & 5.53 \\
Flb & 0.14 & 0.20 & 0.71 & $0.02^{* * *}$ & 0.008 & 2.51 \\
Sigma Sq $\left(\delta^{2}\right)$ & 43.48 & 1.02 & 42.7 & 0.17 & 0.06 & 2.89 \\
Gamma $(\gamma)$ & 0.03 & 0.20 & 0.13 & 0.23 & 0.33 & 0.70 \\
\hline
\end{tabular}

$*, * *$, indicate probability levels at $1 \% \& 5 \%$ respectively.

Table 4 showing the result of nonlinear stochastic models have best fit with the high level of sigma square estimates (43.48 and 42.70). The result of the processing function (Table 4) fitted to the cross section data shows that the stochastic coefficient of the level of the education of the respondents is positively significant at $1 \%$ in the improved processing technique. This explains that the proportionate change in the output of shea nuts processing to the educational level is greater than unity. From this estimate, we can be inferred that one percent increase in their year of education shall lead to 0.05 percent increase in the improved shea nuts processors efficiency. Also in Table 4, the coefficient of processing period is negatively significant at $5 \%$. This explains that the proportionate change in the output of shea nuts processing to processing period is less than unity. Nevertheless, the estimate implies that one percent increase in processing period of one sheabutter production cycle translate to 0.01 percent increase in the inefficiency of the improved processors. This implies that the reduction in the number of days of production translate to an increase in output, hence, wastage is minimized. On the local processing patterns, the Table 4 shows the coefficient of household size to be positively significant at $1 \%$. This indicates that the proportionate change in the output of shea nuts processing to the household size of the respondents is more than one. This estimate implies that; one percent increase in household size would lead to 0.16 percent decrease in the inefficiency of the local shea nuts processors. This could also imply that; the local processors are over dependent on family labour for the processing of shea nuts into sheabutter, showing the complementarity between household size and output of local shea nut processing. And that the family size affects the capacity of women in the processing of shea nuts (Philip et al., 2014). In order to examine the productivity of improved and local shea nuts processing, the 
explanatory variables such as fuel, water, shea nuts and labour were considered relevant for sheabutter production. As shown in Table 4, the fuel and shea nuts quantity used coefficients in the processing function are positively significant at $1 \%$. This explains that, the proportionate change of output of shea nuts processing to the change in fuel and shea nuts quantity used are separately more than unity. It can be inferred from these estimates that one percent increase in fuel and shea nuts used would lead to 3.94 and 0.074 percent increase in output of improved shea nuts processing. The principal material inputs, which are also defined in the system boundary for the material flow analysis framework applied in this study, are fuel-wood (energy), water, and labor (Godfred et al., 2015). On the local shea nuts processing level, the coefficients of the quantity of shea nuts and proportion of family labour are significant at $1 \%$. This explains that the proportionate change in the output of local shea nuts processing to the shea nuts quantity and family labour are more than unity. This implies that one percent increase in the quantity of shea nuts and family labour would lead to 0.004 and 0.02 increase in output of local shea nuts processing respectively. According to Philip et al. (2014) stated that the capacity of women processors depends on the availability of family labour as a source of labour. In the view of Ademola et al. (2012) that quantity of sheabutter produced cannot be determined by any processing techniques is contrary to the findings of this study. In the case of Abedin et al. (2015) shea nuts quality depends on the size of the kernels/nuts and its chemical composition rather than the quantity of kernel/nut.

\section{Conclusion and Recommendations}

The analyzed data result on the level of sheabutter production among processors revealed that respondents that used improved technique produced $48 \mathrm{~kg}$ of sheabutter and local processors did not produce $10 \mathrm{~kg}$ sheabutter per bag of shea nuts each in a week. This showing the significant difference in the output of improved and local shea nuts processing technique. Hence, the technical efficiency of the improved shea nuts processors is higher compared to local processors. The sheabutter production through improved shea nuts processing is increased by fuel and quantity of shea nuts. Meanwhile, the technical inefficiency of the improved processors is decreased and increased by educational level and processing period respectively. On the other hand, the quantity of shea nuts and level of family labour are important in increasing the sheabutter from the local shea nuts processing technique. However, the household size is only significant variable in the study that promotes the efficiency of local shea nuts processing technique. Based on the findings of this study, the following recommendations are suggested for the improvement of shea nuts processing and sheabutter production.

The education and short-term processing technique for sheabutter production is therefore, important and a concerted effort should be made by National Centre for Agricultural Mechanization (NCAM) to create awareness and organize training exercise under the auspices of National Shea butter Association of Nigeria (NASPAN) to extend the benefits of processing shea nuts to sheabutter through improved shea nuts processing technique to the rural 
processors. This will not only ease the drudgery involved in processing activities but also to boost production and allow the processor to diversify their family labour to another profitable enterprise.

Fuel is significant to the production of sheabutter, hence, biomass could be best alternative in terms of cost reduction and discouraging fuel using shea wood.

\section{References}

Abbiw, D.K. (1990). "Useful plants of Ghana, West Africa. Uses of wild and cultivated plants". Intermediate technology publication and the royal botanic gardens, Kew, London, pp. 66-67.

Abedin, A., Abubakar, A.H., Quainoo, A. K., Chimsah, F.A., Nyarko, G., Mahunu, G.K., Abagole, F.K. and Addai, G. (2015). Preliminary Studies on the effect of shea Kernel Size on Sheabutter Quality. Africa Journal of Food Science, 9(4);237242. Doi: 10.5897/AJES2014.1188.

Aboyella, C. (2002). "An economic analysis of shea nuts and cashew production in the Bawku East District". A Bsc. Dissertation submitted to the Department of Economics \& Agribusiness, University of Ghana.

Addaquay, J. (2004), Shea utter Value Chain: Refining in West Africa, WATH Technical Report No. 3

Ademola A.O., Oyesola O.B $>$ Osewa S.O. (2012). Assessment of Sheabutter Processing among Rural Dwellers in ATISBO Local Government Area of Oyo State, Nigeria. European Journal of Business of Social Science, 1(6):108 . http://www.ejbss.com/recent.aspx. ISSN:2235-767X.

Adgidzi, D. (2008). Improving the Sheanut collection, processing, storage and marketing in Niger State A resource paper presented at the workshop organized by the Niger State Shea Butter Products Association held in Minna 21st - 23 October

Ahenkan, A. and Boon, E. (2010) Commercialization of non-timber forest products in Ghana: Processing, packaging, and marketing. Food Agric. Environ.8, 962-969.

Alander, J. 2004. Shea butter - a multifunctional ingredient for food and cosmetics. Lipid Technology, 16(9): 202-205.

Boffa, J-M., Yaméogo,G., Nikiéma, P. and Knudson, D.M. (1996). Shea nut (Vitellaria paradoxa) production and collection in agroforestry parklands of Burkina Faso. Found on FAO website: http://www.fao.org/docrep/W3735e /w3735e17.htm (Accessed August 2008)

Bonkoungou, E.G. (2005). The Shea tree (Vitellaria paradoxa) and the Africa Shea parklands. Proceedings of the international workshop on processing and marketing of Shea products in Africa, Dakar, Sénégal, 4-6 March 2002. Roma: FAO, CFC Technical paper No 21:51-59

Bravo-Ureta, B.E. and Reiger, L. (1990). Alternative Production Frontier methodology and dairy farm efficiency. Journal of agricultural economics, 41:215-226.

Daniel, A., Olufimihan, O., Kwaya, .E. and Odejide, A. (2005). "Shear nut 
processing Raw materials Update." A Bi-annual publication of the Raw Materials Research and development council Abuja, 5(2): 23-30.

Ezema, D.O. and Ogujiofor, K.O. (1992). "The evolution of Butyrospermum paradoxum as a suppository base". International Journal of pharmacognosy, 30: 275280.

Food and Agriculture Organization (FAO). (1991). Postharvest and processing technologies of African staple foods: A technical compendium (FAO Agricultural Services Bulletins No. 89). Rome, Italy: Author.

Godfried, S.J., Osamu, S. and Kazuhiko, T. (2015). Shea (Vitellaria Paradoxa) Butter Production \& Resource Use by Urban \& Rural Processors in Northern Ghana. Sustainability, 7: 3592-3614 Doi: 10.3390/Su7043592. ISSN 20711050.

www.mdpi.com/journal/sustainabili tyarticle

Lovett, P.N. (2004). The Shea butter value chain: production, transformation, and marketing in West Africa. West Africa Trade Hub (WATH) Technical Report No. 2. US-AID West Africa Programme Muhammed, F., Boatang, S. and Alhassan, S. (2013). Effects of Adoption of Improved Sheabutter Processing Technology on Women's Livelihoods and their Microenterprise Growth. America Journal of Humanities and Social
Science 1(4);244-250. Doi: 10.11634/232907811301419.

National Population Commission, (2006). Estimated population figure, National Population Commission of Nigeria, Abuja.

Philip, A., Moses, D. and Konlan, B. (2014). An Analysis of Factors Affecting Women's Capacities as Traditional Shea Butter Processors in Northern Ghana: International Journal of Development Research, 4(4): 942-949.

Ros-Tonen, M.A.F. and Wiersum, K.F. (2005). The scope of improving rural livelihoods through NonTimber Forest Products: An evolving research agenda. For. Trees Livelihoods, 15: 129-148.

Schreckenberg, K., (2004). The contribution of shea butter (Vitellaria paradoxa C.F. Gaertner) to local livelihoods in Benin, Chapter 6 of Forest products, livelihoods, and conservation. Africa Volume 2.

Shackleton, C.M. and Shackleton, S.E. (2004). The importance of nontimber forest products in rural livelihood security and as safety nets: A review of evidence from South Africa. South Afr. J. Sci.100; 658-664.

Yezouma, C., Stephane, O. and Nathalie, N. (2009). Experimental Study of Sheabutter Extraction Efficiency Using A Centrifugal Process. Journal of Engineering and Applied Science (ARPN). 4(6): 14-19. www.arpnjournals.com ISSN: 1819-6608. 